This item was submitted to Loughborough's Research Repository by the author.

Items in Figshare are protected by copyright, with all rights reserved, unless otherwise indicated.

\title{
From mass propaganda to political marketing: the transformation of Labour
}

\section{Party election campaigning}

PLEASE CITE THE PUBLISHED VERSION

PUBLISHER

(C) Frank Cass

LICENCE

CC BY-NC-ND 4.0

REPOSITORY RECORD

Wring, Dominic. 2019. "From Mass Propaganda to Political Marketing: The Transformation of Labour Party Election Campaigning". figshare. https://hdl.handle.net/2134/1107. 
This item was submitted to Loughborough's Institutional Repository by the author and is made available under the following Creative Commons Licence conditions.

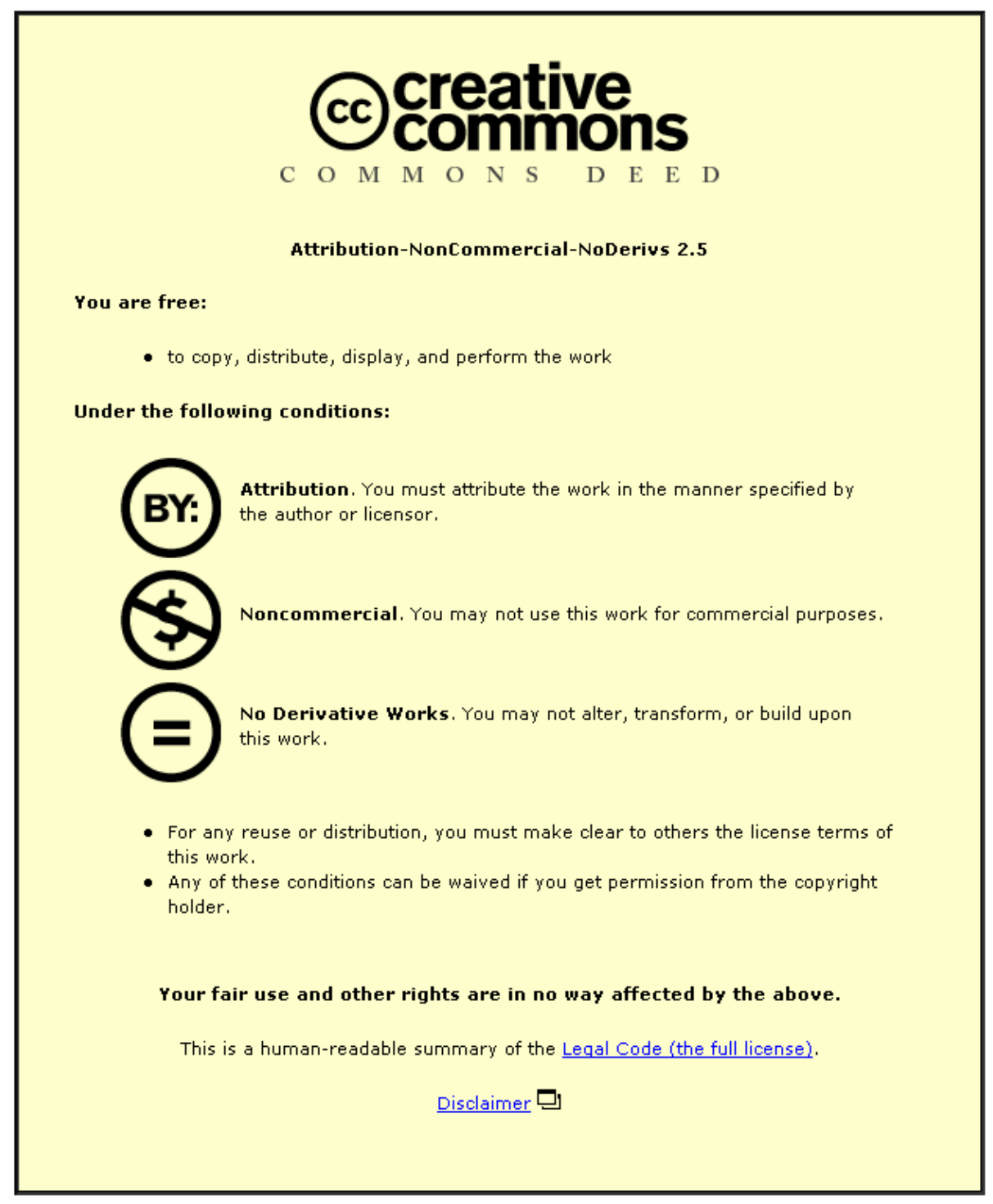

For the full text of this licence, please go to: http://creativecommons.org/licenses/by-nc-nd/2.5/ 


\section{LLoughborough University}

\section{From Mass Propaganda to Political Marketing: the Transformation of Labour Party Election Campaigning.}

(British Parties and Elections Yearbook 1995, Frank Cass 1996)

The rise and growing importance of political marketing is self-evident in many of the major western democracies. ${ }^{1} \quad$ The innovative Conservative party campaign effort of 1979 is sometimes referred to as a major watershed in the development of the phenomenon in Britain. $^{2}$ Results of that election proved a vital component in the respective success of both the agency and client organisation. Victory heralded the beginning of three Thatcher led majority governments as well as the start of a period of commercial success for the party's consultants, Saatchi and Saatchi, culminating in their emergence as the largest advertising agency in the world. ${ }^{3}$ The relationship between the Saatchi team and their most famous clients initiated considerable media interest in the process of professionalised political communications with the implication that the partnership had been crucial to the Conservatives' good fortune. The execution of the 1983 and 1987 general elections consolidated the idea that marketing consultants were becoming an indispensible part of the modern electoral process. In particular television documentaries such as Michael Cockerell's The Marketing of Margaret helped to provoke interest in the new style of campaigning amongst a previously disinterested Labour leadership. ${ }^{4}$

Partly due to the proliferation of media interest in the subject, political marketing is sometimes equated with sophisticated advertising or 'slick' campaigning. A good deal of election coverage has become increasingly preoccupied with the perceived domination of style over substance and image over issue. However, whilst it is true that some marketing approaches to campaigning use 'slick' methods, it is by no means axiomatic that all of them should or do 
pursue the glossy formula. Marketing is more than just presentational devices and advertising, it also relates to product management. Furthermore the process represents not only a set of techniques but also an approach to managing organisational relationships with their publics. ${ }^{5}$ In 1985 the American Marketing Association issued a redefinition of its subject, adding the crucial word 'ideas' to the list of product concerns which further legitimised the application of marketing to electoral politics: 'Marketing is the process of planning and executing the conception, pricing, promotion and distribution of ideas, goods and services to create exchanges that satisfy individual and organizational objectives'. ${ }^{6}$

Arguably the process has begun to play a more significant and central part in contemporary British politics than is suggested by such terms as 'spin-doctoring', 'image-making' or 'powerdressing'. Undoubtedly these techniques form an important (and more obvious) part of some campaigns but they are far from being the sole functions or representations of a political marketing exercise. Increasingly marketing is becoming a central part of strategy as political leaderships attempt to determine, refine and prioritise policy and goals. It is this process of the incorporation of marketing technique and philosophy into party organisational thinking to which this piece now turns. The study will make reference to the historical development of the Labour party as a campaigning unit.

Taken literally Labour began to 'market' itself to a mass electorate in 1918, the year that saw both the introduction of universal suffrage and the first major restructuring of the party apparatus. From this point it is possible to compare the evolution of the Labour party campaign machine with the marketing development of a firm operating in a business environment.

\section{The Stages of Political Marketing Evolution}


In seeking to clarify the stages of political marketing development in Britain it is useful to refer to Avraham Shama's account of changes in American presidential election organisation. ${ }^{7}$ Shama likens the conventional model of commercial marketing development in a firm to the stages in the evolution of a campaigning political party. Consequently three distinctive phases of electioneering can be identified, each directly comparable with the product, sales and market stages of orientation in business marketing. The analogy builds on a theme originally popularised by the democratic theorist Joseph Schumpeter: 'Party and machine politicians are simply the response to the fact that the electoral mass is incapable of action other than a stampede, and they constitute an attempt to regulate political competition exactly similar to the corresponding practices of a trade association. ${ }^{8}$

Shama characterises the period $1940-60$ in American presidential politics as the 'candidate orientation' stage in that campaign organisation resembles a business engaged in a productled marketing strategy. Under this mode of operation politicians began to employ advisors, sometimes professional advertisers, whose chief task was to magnify the candidates' media presence in the belief that the 'number of exposures and length of exposures were taken as the key for victory in the campaign'. The 'product' focused approach to campaigning was preoccupied with maximising name recognition through heavy promotional activity rather than addressing and seeking to assess voters and 'their political needs and wants'.

The era of 'sales management' orientation established itself in the 1960s. During this period campaigners started to develop more rigorous plans which in turn led them to adopt scientific methods of opinion research. Polling was used to solicit information from voters, particularly in respect of how they accessed, used and responded to political communications. Organisers also began to consider techniques for segmenting and targeting voters according to demographic variables. This 'selling concept' approach to electioneering was aimed at presenting a more sophisticated message to a better defined audience though, like the preceding 'candidate orientation' stage of marketing development, its ultimate aims lay in maximising the politician's exposure to the voters. 
Shama develops his analysis by arguing that, as with innovative and successful firms in the commercial sector, politicians can be seen to acquire a 'market orientation' as they embrace a third and more advanced form of campaigning: 'The new marketing concept is interested in the basic political needs and wants of the voters with the intention of offering them candidates who are capable of satisfying these needs and wants or changing existing candidates to meet these needs and wants. ${ }^{9}$ Shama observes that, in seeking to adopt the marketing concept, political organisations use opinion research in order to develop long-term plans and strategic goals rather than just presentational ideas for the last few weeks of an election campaign. Furthermore sophisticated demographic and psychographic market research starts to be fed into the design of the product, be it in relation to the image of a candidate, party or policy platform on which they stand. Marketing techniques such as positioning, segmentation and product development also begin to be more fully integrated into electoral strategy. Shama contrasts this phase of political marketing development with its predecessors in that targets other than just the electorate become the focus of activity. Consequently efforts become partly preoccupied with influencing opinion in the party itself, amongst interest groups and, crucially, the mass media. The relatively novel term 'political marketing' is arguably more credibly used with the realisation of this stage in campaign orientation.

By using Shama's framework, it is possible to discern a similar trend in the development of political marketing in other countries, notably Britain. In particular the evolution of the Labour party organisation can be traced with respect to the changing nature of its electoral approach.

\section{The Era of Mass Propaganda}

The first stage of Labour's organisational development, comparable to a product-led (or candidate orientation) marketing approach, can be traced from the introduction of universal suffrage in 1918 to the advent of mass television nearly forty years later. Analysis of Labour 
campaigning in this period makes it possible to identify the antecedents of modern political marketing. Electioneering activity was commonly referred to as an exercise in 'propaganda'a word which did not have the perjorative connotations it has since acquired. The term is of particular use in describing the one directional flow of communication from political elites to the electorate prior to the growth of widespread public opinion research. Qualter defines propaganda as: 'The deliberate attempt by the few to influence the attitudes and behaviour of the many by the manipulation of symbolic communication. ${ }^{10}$

Prior to assessing the conduct of electioneering in the propaganda era it is worth examining two of the most important environmental factors conditioning the development of Labour campaigning in this period: the nature of headquarters re-organisation and the party's relationship with the mass media.

\section{Party organisation and election campaigning}

The Great War had a profound effect on the way British politicians, including the Labour leadership, viewed the potential of propaganda as a tool of persuasion. Similarly, the passage of the 1918 Representation of the Peoples' Act, guaranteeing universal male suffrage and extending the franchise to some women, also helped increase party organisers' interest in the techniques of mass political communication. This changed electoral environment coincided with the first major overhaul and extension of Labour party headquarters' activity. ${ }^{11}$ Labour formed a Press and Publicity Department in October 1917, just prior to a wholesale review of organisational structure. ${ }^{12}$ Former religious journalist Herbert Tracey headed the new department prior to the appointment of WW Henderson in 1921. A reinvigorated party organisation quickly won praise for its efforts during the 1918 election. ${ }^{13}$ The 1923 and 1929 general election campaigns provided the party with more tangible rewards in the form of its first minority administrations. Soon after the formation of the second government, the Foreign (and party) Secretary Arthur Henderson attributed part 
of Labour's success to 'an unequal standard of organisational and electioneering efficiency'. ${ }^{14}$ Similarly, Dean McHenry, an American scholar writing on the development of Labour party in the 1930s, observed that the organisation 'perhaps surpasses in effectiveness the most highly perfected American political machines sustained by spoils'. ${ }^{15}$

\section{Labour and the mass media}

Study of party political communication has been understandably dominated by discussions of the impact of the mass media. Even prior to the beginning of the twentieth century there were significant changes in the partisan nature of political coverage. Recognising a trend towards more selective and biased reporting in the privately owned print media, Matthews observed that: 'politics began to be more packaged for consumption by the readership of the newspaper'. ${ }^{16}$ The Labour party, in particular, became a major target for press hostility in the form of compromising stories, the most infamous of which became known as the 'Zinoviev letter'. The forged document, published on the front page of the Daily Mail days before the general election of 1924, was widely perceived to have discredited the then minority Labour government with the taint of being pro-Moscow. ${ }^{17}$ Neither did the rise of a heavily regulated state radio broadcasting service, in the shape of John Reith's British Broadcasting Corporation, instill much confidence in a Labour party whose view of the mass media was coloured by the antics of a hitherto dominant print media. ${ }^{18}$ By the 1930 s initial apathy towards the BBC began to develop into hostility with Labour organisers openly questioning the allegedly unjust allocation of party broadcasts in the 1931 general election ${ }^{19}$ and the coverage of Russian affairs in $1933 .^{20}$ If the media provided few opportunities for Labour to promote its message to the British public, the party realised it would have to develop other methods of political communication. Consequently strategists began to assess ways of directly informing the public about the democratic socialist case. The embryo of political marketing development lies in this debate and some of the experimentation with campaign methodology that took place during the period. 


\section{The development of party propaganda technique}

Traditional methods of voter canvassing- meetings, doorstepping and leafleting- provided the basis of Labour party campaigning prior to the advent of the 'television election' in the latter half of the 1950s. However, whilst practical propaganda plans were dominated by these long-established techniques coupled with the narrow calculations of leading politicians, strategists started to appreciate the possibilities presented by the 'new media'. Consequently consideration began to be given to advertising, film-making, image projection and design as well as a rudimentary approach to segmenting and targeting sections of the electorate. Symbolically in 1924 the party commissioned a competition to design its first logo with the winning entry materialising in the form of the shovel, torch and quill design which still appears above the gates of the current headquarters in Walworth Road. ${ }^{21} \mathrm{~A}$ year later party leader Ramsey Macdonald (in a perhaps prophetic move) attempted to change the traditional party song, launching a contest in the Daily Herald to find a replacement for The Red Flag: despite receiving some 300 entries Labour decided to keep its anthem. ${ }^{22}$ In addition leading figures such as Philip Snowden articulated the need for Labour propagandists to make image-laden themes a part of their campaign work:

It is so very easy to bore an audience with facts and figures and statistics. person who uses facts in speaking or writing should remember that the way to impress is to give a mental picture of "relativity". That is an awful word, but what I mean to say is this: To say that we have $1,423,819$ persons unemployed gives no striking and impressive mental picture. But if you say that the number of unemployed could be formed into a procession, four abreast, which would reach from London to Liverpool, you leave a permanent impression on your hearers' minds. ${ }^{23}$ 
It was leading Fabian and political scientist Graham Wallas (pioneer of the phrase 'party image') who noted that 'advertisement and party politics are becoming more and more closely assimilated in method'. ${ }^{24}$ Practical evidence of this came in the 1929 election with the formal introduction of political advertising into the British electoral process in the shape of the employment of the S.H. Benson agency by the Conservatives. ${ }^{25}$ Labour strategists also began to consider the implications of using advertising other than in terms of traditional poster propaganda. Several party thinkers began to explore what one of them called this 'subtle and immeasurable thing' in recognition of the wider societal as well as potential political importance of the new phenomenom: 'few people realise the tremendous force which advertisement has become in modern society, nor the terrific amounts of brains, energy and money that is put into it. ${ }^{26}$

The national party apparatus, however, was not responsible for the most innovative and important Labour advertising campaign of the inter-war period. 1934 had seen the return of a Labour administration led by Herbert Morrison at County Hall, London. Subsequently Morrison sought to overhaul the image of the authority, setting up a new publicity department and employing advertising and public relations techniques in the process. ${ }^{27}$ In the following London County Council elections of 1937 the leader extended the use of professional communications to the capital's Labour party business in what was, his biographers argue, 'the most professional campaign ever fought'. ${ }^{28}$ In securing an impressive re-election victory, Morrison was helped by a group of sympathetic publicity consultants which included Robert Fraser, George Wansborough and Clem Leslie coupled with funds from the T\&GWU and NUGMW unions. ${ }^{29}$ The campaign team produced high quality material promoting the leader and their chosen core campaign themes of education and housing: the message was summed up in one arresting poster image featuring Morrison accompanied by children in front of newly built LCC flats. Early marketing commentators, in the form of Advertising Monthly, applauded the campaign declaring that it had '[set the] standard and made the running for the advertising world itself'. ${ }^{30}$ 
Whilst propaganda was still predominantly thought of in print terms, politicians began to recognise the potential of film as a vehicle for political persuasion. Soon after the First World War the Labour party appointed a group to consider the possible uses of cinematic documentary. Reporting in 1920 Sidney Webb, Chair of the Labour Propaganda Committee, declared:

During the War the Cinematograph became a powerful instrument of propaganda in the hands of the Government. The experience gained in this attractive and striking method of publicity is now being used by capitalist interests in various ways to undermine and check the progress of Labour throughout the country... ${ }^{31}$

As with advertising, key initiatives came from the non-executive level of party organisation. Several groups of supporters such as the Socialist Film Council and ILP Masses and Stage Film Guild sought to promote the medium in the earlier part of the $1930 \mathrm{~s}^{32}$ Despite these efforts, Labour never effectively developed a programme to counter the Conservatives' fleet of cinema vans which became a popular feature of inter-war propaganda. ${ }^{33}$ After the 1935 election defeat the following three annual party conferences played host to important film events. In turn these led to the involvement of documentary makers such as Paul Rotha in discussions about Labour's propaganda methods. Arthur Henderson's successor as party secretary, J.S. Middleton, became convinced of the importance of film as a political medium after attending one of the conference events. The culmination of this activity came with the inauguration of the Workers' Film Association (WFA) in $1938 .^{34}$ The WFA was formed after a period of collaboration between the Labour party, trades unions and experienced film makers in the co-operative movement. Though the group had initially intended to help the Labour party in its election campaigning, the burden of its anti-fascist propaganda activity (and ultimately the war) put an end to these plans. ${ }^{35}$

Prior to the proliferation of opinion polling as a method of campaign feedback after the Second World War Hugh Berrington characterised politicians' relationship to their electorate 
as a 'Dialogue of the Deaf'. ${ }^{36}$ Despite this shortage of data on voters, Labour campaigners actively sought and found ways to better define and target their propaganda at sections of the public. In these activities some of them engaged in a rudimentary type of 'market research' which drew on canvass returns and previous election results. The most important contribution to organisational thinking on the subject came in 1922 with the publication of 'Stratified Electioneering' by Sidney Webb, leading Labour intellectual and creative inspiration behind the recently adopted party constitution. In his influential analysis Webb sought to develop an elementary approach to targeting selected audiences with relevant messages:

we should, as far as possible, 'stratify' our electioneering; appealing to each section of the electorate in the language which that section understands; emphasising just the points in which that section is interested; subordinating the questions that each section finds dull or unpleasant; addressing to each section the literature most appropriate to it; and generally seeking to substitute, for the 'greyness' of mass propaganda, the warmer and more individual colours of each man's speciality. ${ }^{37}$

This conceptualisation, a basic form of political 'market segmentation', made a notable impression on party strategists and earnt the rare honour of a reprint nearly a decade after its initial appearance in the agent's journal Labour Organiser. Several people took up the analysis, including the agent Frank Edwards who showed how it was possible to organise constituency campaigns on the basis of targeting sub-groups of weak Conservatives, Liberals, religious observers and workers by occupation. ${ }^{38}$ Similarly Harold Croft, a highly influential member of the National Union of Labour Organisers, included the stratified electioneering approach in his widely distributed campaign handbook The Conduct of Elections whilst party secretary Arthur Henderson devoted one pre-election address of Lancashire agents to expounding Webb's concept. ${ }^{39}$ The historical significance of stratified electioneering lies in its importance as a precursor to the development of more sophisticated means of political opinion research and segmentation after 1945. 


\section{The Development of the Media Campaign}

The advent of mass television broadcasting in Britain coincided with a proliferation of advertising communications. Both had an immediate impact on society, not least in the sphere of electoral politics. In his model Shama identifies the emergence of a 'sales management' approach to electioneering comparable to the development of what British commentators have termed the 'media campaign'. Consequently the main Westminster parties began to invest in private opinion research and advertising consultancy in order to refine and better target their message. Writing on European party organisational change at this time, Kirchheimer viewed the emerging trend in electioneering as: 'fulfilling in politics a role analogous to that of a major brand in the marketing of a universally needed and highly standardized article of mass consumption. ${ }^{40}$

The new style of media campaigning helped transform the nature of electoral organisation. Identifying what he termed a 'contagion from the right', Epstein cited the importance of the development of 'counter-organisational tendencies' as agents of party change. Subsequently European parties began to eschew the importance of mass-membership campaigning as they moved to adopt modern methods of communication through the employment of advertising and public relations advisers. In concluding his analysis Epstein foresaw the emergence of American style 'middle-class cadre-type organizations'. ${ }^{41}$ Such a course of development can be detected in British politics during and after the 1950s and 1960s.

\section{The 1959 general election}

The decade following the 1955 election has been identified as a key watershed in the development of presentational politics in Britain. This period also marked the entrenchment of conventional marketing in the sphere of civil and economic life, perhaps best encapsulated 
in terms such as 'consumerism' and 'the affluent society'. The 1959 British general election and events leading up to it provided early evidence of the beginning of a major strategic shift in the nature of electioneering. ${ }^{42}$ Conservative Central Office, working in conjunction with leading London advertising agents Colman Prentis and Varley, launched what was generally perceived to be an effective campaign based around the slogan 'Life's Better Under the Conservatives, Don't Let Labour Ruin It'. $^{43}$ For its part the Labour party did not formally embrace such techniques but did commence experimentation with innovative television Party Election Broadcasts(PEBs). The project was supervised by a Broadcasting Advisory Committee which included three MPs with backgrounds in the media, namely Tony Benn, Woodrow Wyatt and Christopher Mayhew (himself the presenter of the first ever small screen Labour PEB during the 1951 general election). Commenting on the 1987 Labour campaign Benn recalled the importance of his earlier party work, describing himself as: 'the Peter Mandelson-Bryan Gould of the 1959 election. I fought a brilliant campaign and lost'. ${ }^{44}$

Both before and after the 1959 general election the nature and desirability of political advertising became the focus of some debate. Commentators such as Richard Crossman denounced the promotion of prime minister Macmillan as a debasement of political debate akin to the selling of detergents. ${ }^{45}$ His fellow Labour MP Alice Bacon, chair of the party National Executive Committee's publicity sub-committee, attacked the Conservatives relationship to the CPV agency in a trenchant parliamentary speech: 'The Conservative Party has placed itself in the hands of an advertising agency which produced the so-called image of the Tory Party by advertising methods. I believe this to be doing something alien to our British democracy'. ${ }^{46}$

Other sections of the party were less inclined to voice partisan criticisms of the Conservatives' professional communications; for them the issue was one of ideological contradiction between what was seen as the capitalist process, with its consumerist tools, and the Labour movement's historic commitment to a socialist vision of society. Writing in 1960, Dennis Potter helped voice the moral indignation on the left for what was perceived to 
be the encroachment of slick advertising and salesmanship into the political process: 'The Prime Minister, Harold Macmillan, is sold on the hoardings of the Mayfair agents of Colman, Prentis and Varley...the techniques of persuasion, the ideology of the acquisitive society, have taken on new and more dangerous dimensions'. ${ }^{47}$

\section{Labour embrace the 'selling concept'}

In the immediate aftermath of the 1959 general election defeat debates over advertising and publicity strategy were unsurprisingly dwarfed by rows between revisionist and traditionalist sections of the Labour party concerning defence policy and Clause Four. ${ }^{48}$ Nevertheless one aspect of modern marketing technique, opinion research, did make some impression during the heated debates over the future and image of the party. In particular the publication of Must Labour Lose?, a venture originally commissioned by the key Gaitskellite journal Socialist Commentary, helped highlight the relevance of political opinion research in giving credence to the revisionist case. ${ }^{49}$ One of the report's authors, Mark Abrams, offered polling evidence which suggested that Labour should reconsider certain standpoints. Specifically the research indicated the party would benefit from shedding its commitments to allegedly unpopular policies such as nationalisation. Must Labour Lose? and its methods were not without its critics particularly amongst traditional socialists who, sharing Aneurin Bevan's view that polling was responsible for 'taking the poetry out of politics', condemned market research and what they saw as the objectification of the voter as a 'political consumer'. ${ }^{50}$ Others disagreed more with Abrams' results and sought to defend the policy of state ownership by citing Gallup data which cast doubt on the argument that this aspect of Labour's programme had helped foster the public's negative perceptions of the party. ${ }^{51}$ Opinion polling had begun to permeate and inform internal political debates, a factor which served to legitimise the techniques and usage of market research within the organisation. 
Just three years after Bacon's statement in the House of Commons Labour embraced advertising and opinion research methods as part of their presentational push under Harold Wilson. The leader, a more consensual figure than his predecessor Hugh Gaitskell, was one of the key factors behind the consolidation of the new approach to party strategy. ${ }^{52}$ Consequently he was able to encourage the assembly of a formidable team of professional publicity consultants including advisors such as David Kingsley. Significantly, Wilson incorporated former advisors to Gaitskell such as pollster Mark Abrams and the new party Director of Publicity John Harris into positions of influence in a revitalised campaign machine. The Conservatives' success at the 1959 election and the Kennedy 'New Frontier' presidential campaign both helped underline the need for an assessment of professional political communications methods inside the party. ${ }^{53}$ Support for an overhaul of party presentation came in the form of articles in several influential publications including Socialist Commentary, the Fabian Society pamphlet series and The Political Quarterly. ${ }^{54}$ The ultimate vindication of the new strategy came with the election of a Labour government in 1964 after an upbeat and innovative campaign that helped promote Harold Wilson and his 'white heat of technology' theme.

Despite his campaign successes in 1964 and 1966, the Labour leader became the focus of criticism after the general election defeat of 1970. Some accused Wilson of running an aloof campaign without care for the rest of the party organisation. ${ }^{55}$ The Labour effort was in marked contrast to the carefully organised efforts of their Conservative opponents who broke new ground through the innovative use of sophisticated polling and advertising methods. ${ }^{56}$ The following elections in 1974 saw little in terms of presentational innovation though they did mark a cementation of the relationship between Labour and the pollsters MORI who had begun to experiment with psychographic research techniques on behalf of their political client. $^{57}$ The campaigns were to be Wilson's last in control and so marked the end of the leadership's longstanding close association with professional election advisors such as Peter Lovell-Davies and Dennis Lyons. 


\section{The Consolidation of Political Marketing}

The third stage of campaign development in Shama's model involves the realisation of a market orientation in electioneering practices. In implementing this new approach, it is possible to identify moves toward what Panebianco calls the 'electoral-professional' ideal type of party organisation. Thus, in this mode, parties become focused on appealing to the 'opinion electorate' rather than their own ideological or membership predilections. ${ }^{58}$ During the 1980 s the Labour party radically reorganised itself. ${ }^{59}$ A key component of this transformation was a two step integration of modern marketing into its campaign structures. Initially, in the build-up to and during the 1987 campaign, sophisticated advertising and opinion research methods were reintroduced to the organisation. Secondly, despite suffering a further defeat, the election served to enhance the leadership to the extent that they were able to introduce a market-led approach into party strategy during the Policy Review.

\section{The adoption of sophisticated techniques}

In contrast to the smooth running Conservative election campaigns of 1979 and 1983, both Labour efforts proved difficult to manage, lacked strategic clarity and were dogged by organisational inertia. Ironically the 1983 election, which resulted in Labour's heaviest defeat since 1931 , was the first to see the party formally retain an advertising agency, Johnny Wright and Partners. Later, making his inaugeral party conference speech as leader, Neil Kinnock invoked the memory of the result in declaring 'Just remember how you felt then, and think to yourselves: "June the Ninth, 1983; never ever again will we experience that"'. The campaign became a by-word for all of Labour's strategic and political failings of the previous years and henceforth acted as a major motivating force behind the reconstruction of the party machine under its new leadership. 
Within a year of the 1983 debacle Labour sympathisers from the world of marketing formed an informal 'breakfast group' to discuss the party communications' problem. ${ }^{60}$ By early 1985 internal pressure groups such as the Labour Co-ordinating Committee were calling for the integration of marketing techniques into party strategic thinking, a view endorsed in a successful motion to the annual conference later that year. ${ }^{61}$ Reflecting on his experiences in the 1983 campaign, Nick Grant, the retiring Director of Publicity recognised a major re-think was underway:

Labour has, at last, come to terms with the need for a clear concise marketing approach- not in order 'to sell politics like soap-powder', but in order to understand the need to develop political marketing as part of the science of communication in the multi-media society in the Britain of the 1980 s and 1990s. ${ }^{62}$

This desire for a new approach to campaigning was highlighted in a memo on party communications prepared by advertising consultant Philip Gould for Grant's successor, Peter Mandelson. The paper offered an in-depth critique of various presentational and organisational failings and proved instrumental in setting up the Shadow Communications' Agency(SCA) in $1986 .{ }^{63}$ The agency consisted of several advertising and marketing specialists all of whom offered their services to Labour on a voluntary basis. Working closely with Mandelson and his new Campaigns and Communications Directorate at Labour headquarters, the SCA co-ordinated a series of events such as the 'Freedom and Fairness' publicity offensive in an attempt to give the party an image overhaul complete with a new red rose logo in preparation for the forthcoming general election. ${ }^{64}$

The 1987 election has been identified as a major watershed in the adoption of marketing by Labour. ${ }^{65}$ Certainly, in terms of technique, the campaign saw the party develop sophisticated machinery geared to the twin tasks of news management and firming up electoral support. In the words of two key strategists their achievement had been to devise: 'one of the most effective pieces of disciplined communication of modern British politics'. ${ }^{66}$ In addition the 
coherent use of marketing tools to promote the party during the campaign surprised the Conservatives, foiled the Alliance parties and helped stabilise Neil Kinnock's hold on the leadership. Despite having led the party to its third major defeat in a row, Kinnock was the recipient of some of the praise for Labour's professional campaign. Given that polling and communication activity was perceived to have been one of the few positive aspects of party endeavours at the time it is perhaps not surprising that it became a key element in the leadership's modernisation strategy during the following parliamentary term. In organisational terms this process of professionalisation afforded the Labour leader(not to mention his successors) 'an institutionalised battery of resources upon which he can draw to enhance his grip over the process of developing party policy and strategy'. ${ }^{67}$

Characteristic of a politician credited with describing the 1983 manifesto as 'the longest suicide note in history', Gerald Kaufman pointedly concluded that the 1987 campaign had been 'a facade'. ${ }^{68}$ In his view the party had not changed enough since 1983 and presentational reforms needed to be supported by a major review of political commitments. This assertion is supported by Swindells and Jardine's contention that, in contrast to the Conservatives, Labour did not 'market' itself but sought to build a campaign around the 'particular narratives of deprivation and poverty and the moral worth of British socialism'. ${ }^{69}$ Commenting after the campaign, Peter Mandelson concluded that Labour needed to extend the use of technique and develop a marketing outlook, especially in respect of of its 'product'the leadership, image and party manifesto: 'Next time, however, we will need to get further in marketing the party on the basis of our programme for government than our professionalism and passion have taken us so far in opposition. ${ }^{70}$

\section{The Policy Review process}

Following on from his first election defeat as leader, and after consultation with close colleagues such as NEC member Tom Sawyer, Neil Kinnock launched Labour's Policy 
Review. The whole exercise, closely monitored by the leadership team, dominated internal party political thinking up until the 1992 election. Whilst the Review formally committed Labour to accepting the workings of the market in the sphere of economic life it also marked a turning point in the party's embrace of another 'market'- in the political domain. Using the criteria set out by Shama, Labour shifted from a sophisticated selling approach to adopt a market orientation devoted to satisfying, in the words of one informed account of the period, 'the needs and concerns of groups of voters'. ${ }^{11}$ The monitoring of public opinion throughout the Review process was to prove crucial in this respect.

Prior to the convening of Policy Review, principally through the formation of individual subject groups, the entire Labour leadership in the shape of a joint meeting between members of the Shadow Cabinet and ruling National Executive Committee were left in little doubt as to what specially commissioned opinion research was saying about their party. The research was, in its implicit advocacy of the need for changes in political strategy, reminiscent of the Must Labour Lose? report- itself a product of a third electoral defeat. The SCA (and associates) briefing, entitled Britain and Labour in the 1990s, influenced the parameters of the subsequent party and review groups' discussions of policy in such a way that 'political demands would be inseparable from the communications imperative'. ${ }^{72}$ This extensive report of public opinion identified a declining base of popular support and the perennial concern of poor party image as Labour's key problems. ${ }^{73}$ Opinion research was commissioned and made available to the policy discussion groups throughout the ensuing review process. Party policy was changed in several areas of perceived electoral weakness, notably in relation to defence, the economy and industrial relations. ${ }^{74}$ Eric Shaw concludes that, as a result of the Policy Review process, Labour developed into a 'responsive' as opposed to an 'educative' party after embracing what he terms an 'electoral imperative' on the basis that: 'No significant development of policy was considered without the most careful attention to likely public responses. ${ }^{.75}$ 
The final stages of the Policy Review involved the promotion of a new, revised party programme. Campaign co-ordinator Jack Cunningham heralded the renewal of Labour for the 1990s in a series of 'pre-manifesto' relaunches beginning with the 'Meet the Challenge, Make the Change' campaign of $1989 .^{76}$

\section{After 1992}

The 1992 election registered a serious blow to the 'new model' Labour party and marked the end of Neil Kinnock's leadership. Yet the organisational changes and thinking that he had pioneered outlasted his period in office. The 'electoral imperative', an apt description of the market orientation embedded in the party's strategy for the 1992 campaign, proved to be one of the factors that played a role in conditioning the cautious debate following the election of John Smith as Labour leader.

Despite the generally bad publicity the polling industry received after failing to predict the 1992 election result, the credibility of market research techniques was not apparently totally damaged inside the Labour party. Interestingly the party inquiry (in conjunction with the SCA) into the fourth defeat used qualitative opinion research undertaken during and after the campaign to try and discover the reasons behind the unexpected fourth Tory victory. Some of the findings, in the form of focus group feedback, were leaked to the press and helped to set an agenda about the reasons behind the party's setback. ${ }^{77}$ Despite the limitations inherent in this type of research, the results were reported by sections of the media as an authoritative source particularly in the absence of other short-term scientific explanations for the setback. Press coverage of the work helped vindicate the leadership's modernisation strategy, blaming past disunity and associations with minority causes for Labour's defeat. ${ }^{78}$ In addition the research was reported to contain evidence which implied links to the trades union movement had proved detrimental to the party's electoral fortunes. The claims contrast with the more modest conclusions of the British Election Study which indicate that Labour suffered as a result of failing to clarify its message. ${ }^{79}$ Nevertheless the focus group post- 
mortem on the party's unexpected 1992 defeat helped shape the political agenda following the election of John Smith as Kinnock's successor.

Besides shaping debate within the party, modern political marketing has also helped redefine the power structures in favour of the leader: the holder of the office not only plays an organisational role but also becomes a central part of the product offering himself. ${ }^{80}$ Consequently even a relatively consensual leader figure such as John Smith was able to initiate, lead and win major debates in his party with some ease. Smith was at the forefront of a 'One Member One Vote' campaign which, whilst being primarily about changing the rules governing parliamentary candidate selections and leadership elections, was widely interpreted as the party seeking to weaken its links to its financial sponsors, the affiliated trades unions. ${ }^{81}$ Similarly a Social Justice Commission was set up to evaluate party policy and possibly allow the instigation of changes to longheld commitments on the welfare state and universal benefits.

Perhaps the clearest evidence of the fundamental shift that has taken place within the Labour party came with the election of Tony Blair as leader. The 1994 ballot for the leadership, involving nearly a million party members and trades unionists, gave a clear majority vote in each section to the candidate of the so-called 'modernisers'. In winning the contest, Blair had been identified in the print media as the prospective leader most likely to win the votes of disaffected Tory and weak Liberal Democrat supporters. Shama noted that, in adopting a market-led approach to campaigning, communications become targeted at groups other than the general public such as the party (in particular those who vote in leadership elections), interest groups (affiliates such as the trades unions) and the agenda-setting mass media. Labour's adoption of such an orientation has helped alter the nature of the party (as well as the overall political environment it operates in) over the course of the last decade. In this way the non-party media, especially the national press, have been able to play an increasingly influential role in internal matters including the recent leadership contests. Thus, in 1994, the newspapers read by the bulk of Labour party members were able to help by running features 
in sympathy with the central message of Blair's case, founded as it was on the belief that he could best realise the party's aspiration to win governmental office. ${ }^{82}$

The market-led renewal strategy pioneered by Kinnock and developed by his successors has not been without its critics in the party. Dissent focuses on two closely related arguments over the political and organisational consequences of Labour adopting a modern marketing campaign approach. Some dissenters, notably Ben Pimlott, have argued that it is unwise to devise political strategy with reference to market research findings on the grounds that such a method is likely to stifle the development of ideas and policies designed to challenge rather than mirror electoral opinion. ${ }^{83}$ Other Labour supporters such as Teresa Pearce, a delegate to the 1992 party conference, have questioned the perceived lack of accountability within the party in terms of its policy formulation and presentation:

We have allowed ourselves to be marketed by paid image makers, but in whose image are we are being made? It is not an image I recognise. It is not an image I want to recognise. We should be beware of the paid image maker. These are people, mainly middle-class graduates, who have learned their socialism from market research and opinion polls. ${ }^{84}$

\section{Conclusion}

The basic premis of this paper has been to compare the development of the Labour party as a campaigning organisation with that of a commercial firm engaged in marketing. Since its first major overhaul of organisational structures in 1918, Labour has been in the business of using marketing techniques in its bid to win electoral support. Marketing did not become a feature of British political life in either the 1959, 1979 or 1992 elections- rather, as Shama observes, it was the basic orientation of the campaigns which changed in light of developments in the market or wider environment. Philip Kotler, one of the leading 
authorities on marketing, contends: 'Campaigning has always had a marketing character. The "new methodology" is not the introduction of marketing methods into politics, but an increased sophistication and acceleration of their use..$^{85}$

Clearly though there was a decisive shift in the nature of Labour party organisation in the periods 1962-64 and more recently after the 1987 defeat. Arguably the adoption of a modern political marketing strategy in the run-up to the 1992 general election was a watershed in a building of a more centralised, disciplined organisation. The change, intended to make Labour electable, has been a contributory factor to the emergence of a strong leadership and more passive party. 


\section{References}

1 Shaun Bowler and David Farrell(eds.), Electoral Strategies and Political Marketing (Hampshire: Macmillan, 1992).

2 Martin Harrop, 'Political Marketing', Parliamentary Affairs, Vol.43: No.3 (1990).

3 Philip Kleinman, The Saatchi and Saatchi Story (London: Weidenfeld and Nicolson, 1987). By the end of the 1980s the Saatchi brothers' fortunes, like those of their political client, were on the wane.

4 See Michael Cockerell, 'The Marketing of Margaret', The Listener, 16 June 1983. The documentary had an impact on the thinking of senior Labour figures such as Robin Cook, the newly appointed party Campaigns Co-ordinator.

5 Geoff Lancaster and Lester Massingham, Essentials of Marketing (Berkshire: McGraw-Hill, 1993, second edition), p.5. Analysis of presentation techniques sometimes forms the basis of commentary on political marketing, for example see Rodney Tyler, Campaign: The Selling of the Prime Minister, (London: Grafton, 1987).

6 Quoted in Seymour Fine(ed.) Marketing the Public Sector (New Jersey: Transaction, 1992), p.1.

7 Avraham Shama, 'The Marketing of Political Candidates', Journal of the Academy of Marketing Sciences, Vol.4, No.4, (1976), pp.764-777.

8 Joseph Schumpeter, Capitalism, Socialism and Democracy (London: Unwin, 1943), p.283.

9 Shama, 'The Marketing of Political Candidates', p.771. It should be noted that whilst the consumer is the focus of the marketing approach the AMA definition of the concept(see note 6) also takes due account of the existence of organisational(i.e. party) objectives. In this way political marketing strategies are not necessarily predicated on the simplistic idea of slavishly following public opinion: recent Conservative campaigns are a good case in point- see Margaret Scammell, 'The Phenomenom of Political Marketing: The Thatcher Contribution', Contemporary Record, Vol.8, No.1, pp.23-43.

10 Terence Qualter, Opinion Control in the Western Democracies (London: Macmillan, 1985), p.124. 
11 Robert McKenzie, British Political Parties (London: William Heinemann, 1955), p.563.

12 Ralph Casey, 'British Politics: Some Lessons in Campaign Propaganda', Public Opinion Quarterly, Spring (1944).

13 Ross McKibbin, The Evolution of the Labour Party 1910-24 (Oxford: Oxford University Press, 1974), p.124.

14 Labour Organiser, No.100, October 1929.

15 Dean McHenry, The Labour Party in Transition 1931-38 (London: George Routlege \& Sons, 1938), p.303.

16 H.C.G. Matthew, 'Rhetoric and Politics in Great Britain, 1860-1950', in P.J. Waller(ed.)

Politics and Social Change in Modern Britain (Sussex: Harvester Press, 1987).

17 A. Jones, 'The Zinoviev Letter', Talking Politics, Vol.5, No.1, Autumn (1992).

18 Labour Organiser, No.79, January 1928.

19 Labour Organiser, No.126, December 1931.

20 Labour Organiser, No.143, May 1933.

21 Labour Organiser, No.42, May 1924.

22 John Gorman, Images of Labour (London: Scorpion, 1985), p.28.

23 Labour Organiser, No.19, April 1922.

24 Graham Wallas, Human Nature in Politics (London: Constable, 1948 edition- first published 1908), p.87.

25 Michael Pinto-Duschinsky, British Political Finance, 1830-1980 (Washington: American Enterprise Institute, 1981), p.98.

26 Labour Organiser, No.178, April 1936.

27 Bernard Donoghue and George Jones, Herbert Morrison: Portrait of a Politician (London: Weidenfeld and Nicolson, 1973), p.207.

28 Ibid., pp.209-10.

29 Fifty years after Herbert Morrison revolutionised his local authority and party publicity machines, similar pioneering campaign methods were being introduced by Ken Livingstone, his Labour successor at County Hall, in an attempt to save the Greater London Council. Likewise, the use of a committee of advertising experts in the 1937 London elections was 
replicated in Labour's high profile 1987 national campaign. Interestingly the latter effort was managed by Morrison's grandson, Peter Mandelson, a party official often credited with introducing professional methods into the Labour party.

30 Labour Organiser, No.193, July 1937.

31 Quoted in Bert Hogenkamp, Deadly Parallels: Film and the Left in Britain, 1929-1939 (London: Lawrence \& Wishart, 1986), p.18.

32 Stephen Jones, The British Labour Movement and Film, 1918-1939 (London: Routledge and Kegan Paul, 1987), pp.141-2.

33 T.J. Hollins, 'The Conservative Party and Film Propaganda Between the Wars', English Historical Review (1981), pp.359-69.

34 Alan Burton, The People's Cinema: Film and the Co-operative Movement (London: British Film Institute, 1994), pp.44-45.

35 Jones, The British Labour Movement and Film, pp.153-4.

36 Hugh Berrington, 'Dialogue of the Deaf? The Elite and the Electorate in Mid-Century Britain', in Dennis Kavanagh(ed.) Electoral Politics (London: Macmillan, 1992).

37 Labour Organiser, No.22, July 1922.

38 Labour Organiser, No.54, June 1925.

39 Labour Organiser, No.89, November 1928.

40 Otto Kirchheimer, 'The Transformation of the Western European Party Systems', in J. La Palombra and M. Weiner(eds.) Political Parties and Political Development (New Jersey: Princeton University Press, 1966).

41 Leon Epstein, Political Parties in Western Democracies (London: Pall Mall, 1967), p.257.

42 Richard Rose, Influencing Voters: A Study of Campaign Rationality (London: Faber and Faber, 1967). It is significant that this book, the most penetrating analysis of the new media mode of campaigning in Britain, appeared soon after the emergence of the phenomenom in the post-war era.

43 David Butler and Richard Rose, The British General Election of 1959, (London: Macmillan, 1960).

44 The Guardian, 11 July 1992. 
45 Butler and Rose, The British General Election of 1959, p.27.

46 Rose, Influencing Voters, p.14.

47 Dennis Potter, The Glittering Coffin (London: Victor Gollancz, 1960), p.15.

48 For background on the major actors in this period see: Mark Jenkins, Bevanism: Labour's High Tide (Nottingham: Spokesman, 1979); and Stephen Haseler, The Gaitskellites (London: Macmillan, 1969).

49 Mark Abrams and Richard Rose with Rita Hinden, Must Labour Lose? (London: Penguin, 1960).

50 Raphael Samuel, 'Dr Abrams and the End of Politics', New Left Review, No.5, September (1960).

51 Geoffrey Gibson, 'Voting Habits are Examined', Labour Organiser, No.486, December (1962). See also the edition from December 1960.

52 Stephen Fielding, 'The Evolution of "Wilsonism": "White heat" and white collars', in R. Coopey, S. Fielding and N.Tiratsoo(eds.), The Wilson Governments, 1964-70 (London: Pinter, 1993).

53 On the Kennedy election campaign see Theodore White, The Making of the President 1960 (London: Jonathan Cape, 1962).

54 See for instance Christopher Rowland, Labour Publicity, Political Quarterly, Vol.31, July (1960).

55 Labour MP Leo Abse called for an inquiry into Wilson's behaviour during the campaignDick Leonard, 'The Labour Campaign', in H.R. Penniman(ed.)Britain at the Polls 1974 (Washington: American Enterprise Institute, 1975).

56 Barry Day, 'The Politics of Communication or the Communication of Politics', in Robert Worcester and Martin Harrop(eds.), Political Communication: The General Election of 1979 (London: Allen \& Unwin, 1982).

57 Robert Worcester, British Public Opinion (Oxford: Blackwell, 1991), p.48.

58 Angelo Panebianco, Political Parties: Organisation and Power (Cambridge: Cambridge University Press, 1988), pp.263-4. The point about the difference between modern political marketing and earlier forms of electioneering is perhaps reinforced by Rose's study of 
campaign rationality(see note 42) which concluded that the 'media' approach (the focus of his research) was restricted by parties' reticence to use opinion research as a feedback mechanism.

59 See Paul Webb, 'Election campaigning, organisational transformation and the professionalisation of the Labour Party', European Journal of Political Research, Vol.21, pp.267-288 (1992); also Adrian Sackman, 'Managers and Professionals in Neil Kinnock's Labour Party 1983-87: A Case Study of Campaign Management', paper presented at the European Consortium of Political Research joint sessions, Leiden, April (1993); and John Wilton, 'Labour in the 1980s: the effect of professionalisation on party campaigning', paper presented at the Political Studies Association Conference, Leicester, April (1993).

60 The Guardian, 2 October 1989.

61 The Guardian, 30 January 1985; Labour Party Annual Conference Report (London: Labour Party, 1985).

62 Nick Grant, 'A comment on Labour's campaign', in Ivor Crewe and Martin Harrop(eds.) Political Communication and the General Election of 1983 (Cambridge: Cambridge University Press, 1986).

63 David Butler and Dennis Kavanagh, The British General Election of 1987, (London: Macmillan, 1988).

64 Andrew Grice, 'Political Advertising: How Labour staged a marketing revolution', Campaign, 30 May 1986.

65 Martin Harrop, 'Political Marketing'.

66 Patricia Hewitt and Peter Mandelson, 'The Labour Campaign', in Ivor Crewe and Martin Harrop(eds.), Political Communication in the the 1987 General Election Campaign (Cambridge: Cambridge University Press, 1989).

67 Paul Webb, 'Party Organizational Change in Britain: The Iron Law of Centralisation?', in

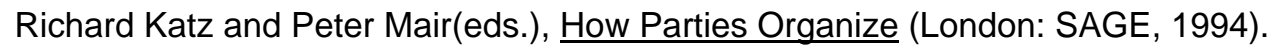

68 Remark made in an interview shown on London Weekend Television's series Kinnock: The Inside Story, broadcast on the ITV network, August 1993. 
69 Julia Swindells and Lisa Jardine, What's Left: Women in Culture and the Labour Movement (London: Routledge, 1990), p.viii.

70 Peter Mandelson, 'Marketing Labour', Contemporary Record, Winter (1988). Press reports highlighting dicussions over the need for the party to make serious changes to its policies began to appear soon after the 1987 defeat- for instance 'Labour told to adapt policy or face defeat', The Times, 27 July 1987.

71 Colin Hughes and Patrick Wintour, Labour Rebuilt: the New Model Party (London: Fourth Estate, 1990), p.46.

72 Ibid., p.54. See also discussion of the importance of the research, pp.60-63. The documentary series Kinnock: The Inside Story(see note 60) placed particular emphasis on the impact of this research on the Policy Review process. Furthermore, the polling provided a clear and coherent source of information when contrasted with other Review inputs such as the quickly abandoned Labour Listens exercise.

73 David Butler and Dennis Kavanagh, The British General Election of 1992 (London: Macmillan, 1992), p.60.

74 Hughes and Wintour, Labour Rebuilt, polling was fed to important review group discussions on defence(p.109), the economy(pp.137-8) and party image(p.153).

75 Eric Shaw, 'Towards Renewal? The British Labour Party's Policy Review', West European Politics, Vol.16, No.1, January (1993); the phrases 'educative' and 'responsive' come from the same author's 'The Triumph of Professionalism? Labour's Communications Strategy and the 1992 Election Campaign', paper presented to the European Consortium of Political Research, Leiden, April (1993).

76 Jack Cunningham, 'Get the Message', New Socialist, October/November (1990).

77 Reports of the polling appeared in several titles including The Guardian, 12 June 1992, The Financial Times, 17 June and The Sunday Times, 21 June.

78 Commentary in The Guardian, 12 June 1992, indicated that floating voters saw the party as 'too old fashioned, too tied to the past, too linked to minorities and old images of the trades unions'. The debate over the uses of focus group research methods is discussed in J.L. Drayton et al., 'The Focus Group: A Controversial Research Technique', Graduate 
Management Review, Winter (1989); also D.L. Morgan(ed.), Successful Focus Groups (London: SAGE, 1993).

79 Anthony Heath et al, Labour's Last Chance? (London: Dartmouth, 1994).

80 Michael Foley, The Rise of the British Presidency (Manchester: Manchester University Press, 1993).

81 Andy McSmith, John Smith (London: Mandarin, 1994).

82 Patrick Seyd and Paul Whiteley, Labour's Grassroots (Oxford: Clarendon, 1992), p.37over $60 \%$ of party members were reported as either readers of The Guardian or Daily Mirror/Record titles. Both these papers, together with sections of the non-Labour supporting press, ran several features in sympathy with Blair and the message of his campaign- see Tariq Ali, 'The British Clinton?', New Statesman and Society, 20 May 1994.

83 Ben Pimlott, 'The Future of the Left', in Robert Skidelsky(ed.) Thatcherism (London: Chatto and Windus, 1988).

84 Labour Party, Annual Conference Report (London: Labour Party, 1992), p.68. For a detailed discussion on the opposition to the modernisation strategy see Richard Heffernan and Mike Marqusee, Defeat from the Jaws of Victory: Inside Kinnock's Labour Party (London: Verso, 1992).

85 Philip Kotler, 'Voter Marketing: Attracting Votes', in Marketing for Non-profit Organizations (New Jersey: Prentice-Hall, 1982). 


\section{Abstract(Wring).}

In order to trace the historical transformation of electioneering in Britain it is useful to draw on an evolutionary model popular in marketing. Three different periods of campaigning can be identified, each comparable with what are known as the product, sales and market orientations in the development of a commercial strategy. With reference to electoral politics, the respective phases can be labelled as the propaganda, media and political marketing approaches to electioneering. Using this framework it is possible to understand the important if previously largely unrecognised part that basic marketing concepts have played throughout the campaigning life of the Labour party in Britain. Contrary to popular perceptions, advertising and image consciousness have had a place in party strategists' considerations ever since the granting of near universal suffrage in 1918 ushered in an era of mass electoral propaganda. The realisation of popular television in the 1950s exacerbated the need for image management and soon after Labour, under Harold Wilson, openly embraced media campaigning and the advice of professional publicists. With the embrace of the final stage in political marketing development during the Kinnock leadership it is possible to offer an understanding of the depth and scale of change that has taken place in Labour party organisation since the 1983 defeat. 
27

28

29

30

31

32

33

34

35

36

37

38

39

41

42

43

44

45

46

47

48

49

50

51

52

53

54

55

56

57

58

59

60

61

62

63

64

65

66

67

68

69

70

71

72

73

74

75

76

77

78

79

80

81

82

83

84

85 